\title{
Evaluation of antidepressant effect of angiotensin receptor blocker telmisartan in albino mice
}

\author{
Keerthana Brattiya*, Malar Sivaraman
}

Department of Pharmacology, Government Kilpauk Medical College, Chennai, Tamilnadu, India

\author{
Received: 09 December 2019 \\ Revised: 27 January 2020 \\ Accepted: 29 January 2020 \\ *Correspondence: \\ Dr. Keerthana Brattiya, \\ Email: dazzle87@gmail.com
}

Copyright: $(\odot$ the author(s), publisher and licensee Medip Academy. This is an open-access article distributed under the terms of the Creative Commons Attribution Non-Commercial License, which permits unrestricted non-commercial use, distribution, and reproduction in any medium, provided the original work is properly cited.

\begin{abstract}
Background: Depression and hypertension are common morbidities which are seen in elderly and also one leads to the other. Present antidepressant drugs are known for its side effects and there is a necessary for newer drugs with lesser adverse effects. Telmisartan being a widely used antihypertensive drug and with multiple additional properties like peroxisome proliferator-activated receptor gamma activity along with blunting of renin-angiotensin-aldosterone system can be a potential drug for depression. Hence this study is aimed to evaluate the antidepressant activity of angiotensin receptor blocker telmisartan in animal models.

Methods: As per protocol submitted to ethics committee, 24 male albino mice weighing between 20-30grams of either sex were selected and divided into 4 groups consisting of 6 each. They were housed in cages with food and water ad libitum. Animals were kept in ambient temperature and humidity, with a 12-hour light and 12-hour dark cycle. Group 1 and group 2 were administered distilled water and fluoxetine $10 \mathrm{mg} / \mathrm{kg}$ respectively only on day 15 , whereas group 3 and group 4 received telmisartan per orally $1 \mathrm{mg} / \mathrm{kg}$ and $2 \mathrm{mg} / \mathrm{kg}$ respectively for 15 days once daily. All animals were tested on day 15 using tail suspension test for antidepressant effect.

Results: There was significant reduction in the immobility time in telmisartan group when compared to the control group and this time was comparable with the immobility time of standard drug fluoxetine. Decrease in immobility time was found to statistically significant by using one-way ANOVA followed by Bonferroni post hoc test.

Conclusions: As evident from our study, telmisartan can be a newer target for antidepressant effect.
\end{abstract}

Keywords: Telmisartan, Antidepressant, Peroxisome proliferator-activated receptor gamma

\section{INTRODUCTION}

Depression is now standing amongst the leading causes of morbidity and mortality. Being a difficult to diagnose condition and with multiple causative factors it is necessary for treating them properly. Many theories have been proposed for cause of depression including cognitive theory of depression, hormonal theory of depression, atrophic theory of depression involving defective neurogenesis, genetic variations and inflammatory mediated with serotonin, gamma aminobutyric acid (GABA), nor epinephrine etc. ${ }^{1}$ Also depression and hypertension has been evaluated to be co existent and goes hand in hand, it is reported to be as high as $18-37 \% .^{2}$ Studies have also demonstrated that it's a viscous cycle they get depressed for being hypertensive ,making them take multiple medications and in addition geriatric age group population having confusion of polypharmacy, ending up with increased morbidity.

Many new drugs are been in discovery to treat depression and to overcome the side effects caused by present antidepressant drugs. One such drug is Telmisartan, 
angiotensin receptor blocker with additional proliferatoractivated receptor (PPAR) gamma properties. There have been evidences supporting the role of renin angiotensin aldosterone system (RAAS) in the changes involved in control of cognition and various activities. Blunting of RAAS system has been shown to improve depression. ${ }^{3,4}$ Human studies, involving patients taking renin modifying drugs were found to have less percentage of depression. Hence the present study is to evaluate effect of Telmisartan on depression in animals.

\section{METHODS}

As per protocol submitted to Institutional Animal Ethics Committee, 24 male albino mice weighing between 20-30 grams of either sex were selected and divided into 4 groups consisting of 6 each. They were housed in cages with food and water ad libitum. Animals were kept in ambient temperature and humidity, with a 12-hour light and 12-hour dark cycle. Drugs used in experiment were distilled water, tablet fluoxetine $(10 \mathrm{mg} / \mathrm{kg})$ and tablet telmisartan $(1 \mathrm{mg} / \mathrm{kg}$ and $2 \mathrm{mg} / \mathrm{kg})$. Drugs were crushed using mortar and pestle and dissolved using distilled water.

Group 1 and group 2 were administered distilled water and fluoxetine $10 \mathrm{mg} / \mathrm{kg}$ respectively only on day 15 , whereas group 3 and group 4 received telmisartan per orally $1 \mathrm{mg} / \mathrm{kg}$ and $2 \mathrm{mg} / \mathrm{kg}$ respectively for 15 days once daily (Table 1). On day 15 assessment of antidepressant effect was observed in all animals.

Table 1: Methodology of drug administration in each group.

\begin{tabular}{|c|c|c|}
\hline Groups & Day (1-14) & Day15 \\
\hline 1 & - & $\begin{array}{l}\text { Control- distilled water }(0.5 \\
\mathrm{ml})\end{array}$ \\
\hline 2 & - & $\begin{array}{l}\text { Standard- fluoxetine (10 } \\
\text { mg/kg p.o) }\end{array}$ \\
\hline 3 & $\begin{array}{l}\text { Telmisartan } \\
1 \mathrm{mg} / \mathrm{kg} \text { p.o. }\end{array}$ & Telmisartan $1 \mathrm{mg} / \mathrm{kg}$ \\
\hline 4 & $\begin{array}{l}\text { Telmisartan } \\
2 \mathrm{mg} / \mathrm{kg} \text { p.o. }\end{array}$ & Telmisartan $2 \mathrm{mg} / \mathrm{kg}$ \\
\hline
\end{tabular}

\section{Assessment with tail suspension method}

The tail suspension test (TST) developed by Steru is used. ${ }^{5}$ Drugs after administering for 15 days to group 3 and 4 were bought for testing. Group 1 and 2 also received their drugs on day 15 and half an hour after administration all animals were tested on day 15 .

Animals are suspended from a height of $35 \mathrm{~cm}$ above table in a horizontal rod placed on 2 metallic stands by adhesive tape placed $2 \mathrm{~cm}$ proximal to the tip of the tail. Immobility time in seconds was recorded for $6 \mathrm{~min}$. Mice are considered immobile when they hung passively and motionless. All the animals were handled as per CPCSEA guidelines, New Delhi, India.

\section{Statistics}

Decrease in immobility time was considered as statistically significant result based on one way ANOVA followed by Bonferroni post hoc test and probability of $p$ value $<0.05$ was considered significant.

\section{RESULTS}

On day 15 the animals were subjected to tail suspension test and their findings were noted. Duration of immobility in group 1 was $248 \pm 18$ seconds which was reduced to $171 \pm 23$ seconds for the fluoxetine group. Telmisartan group also had significant reduction in duration of immobility which was in line with the Fluoxetine group. The duration was $175 \pm 29$ seconds for the telmisartan 1 $\mathrm{mg} / \mathrm{kg}$ group and $142 \pm 24$ seconds for the telmisartan 2 $\mathrm{mg} / \mathrm{kg}$ group, which was highly significant and proving our hypothesis of telmisartan's antidepressant property. Telmisartan $2 \mathrm{mg} / \mathrm{kg}$ was more effective in reducing the mobility time than telmisartan $1 \mathrm{mg} / \mathrm{kg}$ group.

Table 2: Effect of chronic treatment of telmisartan on mice using TST.

\begin{tabular}{|lll|} 
Group & $\begin{array}{l}\text { Treatment (dose in } \\
\text { mg/kg) }\end{array}$ & $\begin{array}{l}\text { Duration } \\
\text { immobility in } \\
\text { sec (mean } \pm \text { SD) }\end{array}$ \\
\hline $\mathbf{1}$ & $\begin{array}{l}\text { Control group- distilled } \\
\text { water }\end{array}$ & $248 \pm 18$ \\
\hline $\mathbf{2}$ & $\begin{array}{l}\text { Standard- fluoxetine 10 } \\
\text { mg/kg p.o }\end{array}$ & $171 \pm 23^{*}$ \\
\hline $\mathbf{3}$ & Telmisartan 1 mg/kg p.o & $175 \pm 29^{*}$ \\
\hline $\mathbf{4}$ & Telmisartan 2 mg/kg p.o & $142 \pm 24^{*}$ \\
\hline
\end{tabular}

Mean \pm SD with one-way ANOVA followed by Bonferroni post Hoc test show the results are highly significant with $\mathrm{p}<0.001$.

\section{DISCUSSION}

The finding of this study shows that telmisartan has significant antidepressant activity when compared with standard drug fluoxetine, an SSRI which is prescribed widely for depression. Polypharmacy is common in elderly age group due to many co morbidities. Further present antidepressant drugs have multiple side effects and there is a necessity for newer drugs for treatment of depression.

Depression and hypertension are common seen in elderly age group hence this study was taken up to know if telmisartan a commonly used hypertensive drug has any effect on depression which can provide additional effect as an anti-depressant agent. It has also been proved that telmisartan has long half-life and also being lipophilic can cross blood brain barrier, for activation of its central receptors. ${ }^{6,7}$ Previous studies have showed to have this effect with drugs like ramipril, fosinopril and losartan. ${ }^{8}$ 
Telmisartan in addition with AT1 receptor blockade it also has PPAR gamma agonistic activity which has improved anti-inflammatory and antioxidant effect thereby providing neuroprotection against ischemia and amyloid deposits. ${ }^{9}$ It's neuroprotection has been proved in studies by reduction in the levels of interleukin and TNF alpha. ${ }^{10}$ Another study showed that telmisartan has an effect on improving the PPAR delta receptors and also increasing the hippocampal activity of PPAR thereby improving depression. ${ }^{11}$ A study by Wang et al mentioned telmisartan as a very promising neuroprotective compound and substantiates the therapeutic use of this drug in neurodegenerative diseases and traumatic brain disorders where glutamate neurotoxicity plays a significant role. ${ }^{12}$ Saavedra et al mentions that the use of sartans may be beneficial for the treatment of many brain disorders. ${ }^{13}$

\section{CONCLUSION}

As evident from our study, Telmisartan can be a newer target for antidepressant effect and further studies are required to extrapolate this effect on patients. It can be used in hypertensive patients suffering with depression, to improve their quality of life when two drugs are needed.

Funding: No funding sources Conflict of interest: None declared

Ethical approval: The study was approved by the Institutional Ethics Committee

\section{REFERENCES}

1. Hasler G. Pathophysiology of depression: do we have any solid evidence of interest to clinicians? World Psychiatr. 2010;9(3):155-61.

2. Simonsick EM, Wallace RB, Blazer DG, Berkman LF. Depressive symptomatology and hypertensionassociated morbidity and mortality in older adults. Psychosom Med. 1995;57(5):427-35.

3. Wright JW, Yamamoto BJ, Harding JW. Angiotensin receptor subtype mediated physiologies and behaviors: New discoveries and clinical targets. Prog Neurobiol. 2008;84(2):157-81.

4. Guimond MO, Payet NG. "The Angiotensin II Type 2 Receptor in Brain Functions: An Update. Inter J Hypertens. 2012;2012.
5. Steru L, Chermat R, Thierry B, Simon P. The tail suspension test: a new method for screening antidepressants in mice. Psychopharmacol. 1985;85(3):367-70.

6. Noda A, Fushiki H, Murakami Y, Sasaki H, Miyoshi S, Kakuta H, Nishimura S. Brain penetration of telmisartan, a unique centrally acting angiotensin II type 1 receptor blocker, studied by PET in conscious rhesus macaques. Nuclear Med Biol. 2012;39(8):1232-5.

7. Wang JM, Tan J, Leenen FH. Central nervous system blockade by peripheral administration of AT1 receptor blockers. J Cardiovasc Pharmacol. 2003;41:593-9.

8. Nayak V, Patil PA. Antidepressant activity of fosinopril, ramipril and losartan, but not of lisinopril in depressive paradigms of albino rats and mice. Ind $\mathbf{J}$ Experiment Biol. 2008;46(3):180-4.

9. Kasahara Y, Taguchi A, Uno H, Nakano A, Nakagomi T, Hirose H, et al. Telmisartan suppresses cerebral injury in a murine model of transient focal ischemia. Brain Res. 2010;1340:70-80.

10. Kobayashi T, Kawamata T, Shibata N, Okada Y, Kobayashi M, Hori T. Angiotensin II type 1 receptor blocker telmisartan reduces cerebral infarct volume and peri-infarct cytosolic phospholipase A2 level in experimental stroke. J Neurotr. 2009;26(12):2355-64.

11. Li Y, Cheng KC, Liu KF, Peng WH, Cheng JT, Niu HS. Telmisartan activates PPAR $\delta$ to improve symptoms of unpredictable chronic mild stressinduced depression in mice. Scientific Reports. 2017;7(1):1-1.

12. Wang J, Pang T, Hafko R, Benicky J, SanchezLemus E, Saavedra JM. Telmisartan ameliorates glutamate-induced neurotoxicity: roles of AT (1) receptor blockade and PPARgamma activation. Neuropharmacol. 2014;79:249-61.

13. Saavedra JM. Angiotensin II AT (1) receptor blockers as treatments for inflammatory brain disorders. Clin Sci (Lond). 2012;123:567-90.

Cite this article as: Brattiya $\mathrm{K}$, Sivaraman $\mathrm{M}$. Evaluation of antidepressant effect of angiotensin receptor blocker telmisartan in albino mice. Int $\mathrm{J}$ Basic Clin Pharmacol 2020;9:446-8. 